\title{
PERENCANAAN PENGGUNAAN PLTS DI STASIUN KERETA API CIREBON JAWA BARAT
}

\author{
Zalmadi Syamsudin ${ }^{1)}$, Syarif Hidayat ${ }^{2}$, Muslimin Nur Effendi ${ }^{3)}$ \\ Teknik Elektro, Sekolah Tinggi Teknik - PLN \\ 'zalmadi@sttpln.ac.id, \\ ${ }^{2}$ syarifhidayat@sttpln.ac.id \\ ${ }^{3}$ muslimin_NE@gmail.com
}

\begin{abstract}
Utilization of solar cell technology as a source of electrical energy in Indonesia is still not well developed whereas Indonesia is located on the equator so it gets abundant sunshine. Technology should be maintained for the future of technology is environmentally friendly, one PLTS. SPP is a power generation system that converts solar energy into electricity through a photovoltaic module that is included in the green energy to become a renewable generator. The results show for the time being the use of solar systems, especially at the train station to meet its electricity needs not be economically viable. This is due to the high investment cost of solar systems compared with the cost of electricity purchased from conventional sources. However, sensitivity analyzes carried out showed solar systems became feasible in some conditions.
\end{abstract}

Keywords: Solar cell, train station, sensitivity analysis.

Abstrak : Pemanfaatan teknologi sel surya sebagai sumber energi listrik di Indonesia masih belum berkembang baik padahal Indonesia terletak di garis khatulistiwa sehingga mendapat sinar matahari yang melimpah. Teknologi yang patut dipertahankan untuk masa depan adalah teknologi ramah lingkungan, salah satunya PLTS. PLTS adalah sistem pembangkit listrik yang mengubah energi matahari menjadi energi listrik melalui photovoltaic module yang termasuk dalam green energy sehingga menjadi suatu pembangkit yang terbarukan. Hasil penelitian menunjukkan untuk saat ini penggunaan sistem PLTS khususnya di stasiun kereta untuk memenuhi kebutuhan listriknya tidak menguntungkan secara ekonomis. Hal ini karena tingginya biaya investasi sistem PLTS dibandingkan dengan biaya listrik yang dibeli dari sumber konvensional. Namun analisis sensitivitas yang dilakukan menunjukkan sistem PLTS menjadi layak pada beberapa kondisi.

Kata Kunci : Sel surya, stasiun kereta, analisis sensitivitas.

\section{PENDAHULUAN}

Keberadaan energi listrik dirasakan sangat penting demi terselenggaranya pembangunan nasional. Baik secara langsung maupun tidak langsung, energi listrik membantu dalam pemenuhan aktivitas sehari-hari di masyarakat. Dalam melakukan pemenuhan kebutuhan energi listrik di seluruh Indonesia, negara telah mengaturnya dengan pasal 33 ayat (2) Undang-Undang Dasar Negara Republik Indonesia tahun 1945 yang menyatakan bahwa usaha penyediaan tenaga listrik dikuasai oleh Negara dan dipergunakan untuk sebesar-besar kemakmuran rakyat yang penyelenggaraannya dilakukan oleh pemerintah dan pemerintah daerah.

Untuk mendukung upaya tersebut, maka pemerintah memberi wewenang sepenuhnya kepada PT. Perusahaan Listrik Negara (Persero) untuk menyediakan dan mengatur distribusi listrik ke seluruh Indonesia guna mendukung pertumbuhan ekonomi sesuai dengan Undang-Undang No.15 tahun 1985. Tetapi pada kenyataannya, PT. PLN (Persero) masih kesulitan dalam pemenuhan 
kebutuhan energi listrik ke seluruh Indonesia. Sampai tahun 2014, tercatat bahwa rasio elektrifikasi nasional adalah 84,35\% (DJLPE, KESDM, Januari 2015). Pengertian rasio elektrifikasi sendiri adalah tingkat perbandingan jumlah penduduk suatu negara yang menikmati listrik dengan jumlah total penduduk di negara tersebut. Angka tersebut masih lebih kecil dibandingkan dengan angka rasio elektrifikasi di negara-negara tetangga Indonesia seperti contohnya di Singapura yang sudah mencapai angka $100 \%$ serta Malaysia dan Brunei Darussalam telah melebihi angka 90\% seperti yang dikemukakan M. Fadhil Hasan dari Institute for Development of Economics and Finance Indonesia.

\section{LANDASAN TEORI}

Pembangkit listrik berfungsi menghasilkan energi listrik melalui proses generator listrik. Energi listrik yang dihasilkan merupakan proses konversi dari sumber energi primer yang dapat berupa energi baru terbarukan (EBT) atau bahan bakar.

\subsection{SelSurya}

Photovoltaic terdiri atas 2 kata, yaitu "photo" yang berarti cahaya dan "voltaic" yang berarti listrik. Teknologi photovoltaic adalah istilah yang digunakan untuk menjelaskan untuk mengubah energi surya (matahari) menjadi energi listrik. Material yang digunakan adalah semikonduktor yang mampu untuk melepas elektron, bentuk dasar dari listrik. Semikonduktor yang banyak digunakan pada sel fotovoltaik adalah silikon.

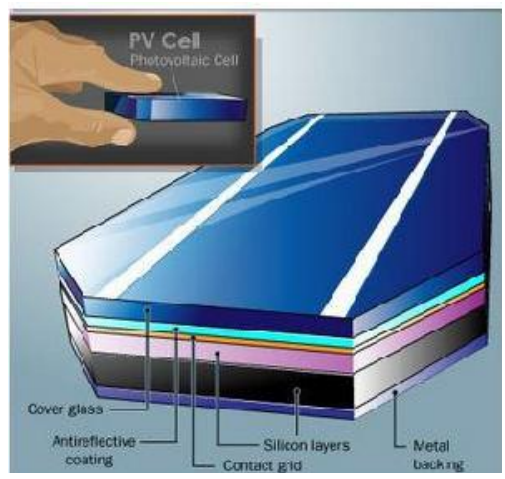

Gambar 2.1 Struktur Sel Surya

\subsection{Pembangkit Listrik Tenaga Surya (PLTS)}

Pembangkit Listrik Tenaga Surya (PLTS) adalah peralatan pembangkit listrik yang dapat mengkonversikan energi cahaya matahari menjadi listrik arus searah. Pembangkitan listrik bisa dilakukan dengan dua cara, yaitu secara langsung menggunakan fotovoltaik dan secara tidak langsung dengan pemusatan energi surya.

Pada siang hari modul surya menerima cahaya matahari yang kemudian diubah menjadi listrik melalui proses fotovoltaik. Listrik yang dihasilkan oleh panel surya dapat langsung disalurkan ke beban DC maupun dapat disimpan dalam baterai, sebelum digunakan ke beban. Pada malam hari dimana panel surya tidak menghasilkan listrik sehingga listrik yang sudah terkumpul di dalam baterai dapat digunakan.

Diantara penyaluran listrik dari modul surya ke baterai, ada suatu alat kontroler (charge controller) yang akan mengatur proses pengisian baterai, listrik yang dihasilkan pada modul surya berupa arus searah (DC), untuk mengubah arus searah (DC) menjadi arus bolak balik (AC) diperlukan alat tambahan yang disebut inverter.

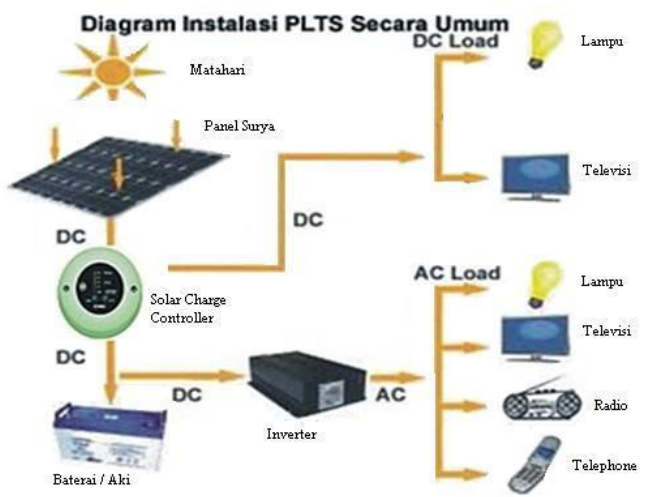

Gambar 2.2 Skema Instalasi PLTS

\subsection{Komponen Sistem PLTS}

1. Modul Surya

Modul surya berfungsi untuk mengkonversi energi matahari menjadi energi listrik DC. Secara prinsip, modul surya terdiri dari beberapa sel fotovoltaik yang disambung spesifik untuk menghasilkan arus DC sesuai spesifikasi output. 


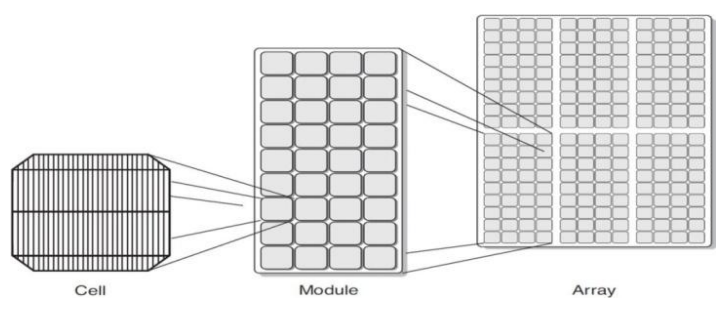

Gambar 2.3 Sel, Modul dan Array Surya

Semakin tinggi efisiensi modul surya, semakin besar daya listrik yang dihasilkan oleh modul tersebut untuk luas modul yang sama.

\section{Solar Charge Controller}

Solar Charge Controller adalah peralatan elektronik yang digunakan untuk mengatur arus searah yag diisi ke baterai dan diambil dari baterai ke beban. Solar charge controller mengatur overcharging (kelebihan pengisian karena baterai sudah "penuh") dan kelebihan tegangan dari panel surya.

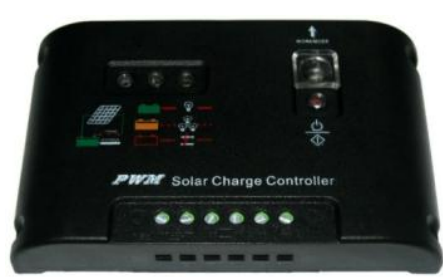

Gambar 2.4 Solar Charge Controller

\section{Baterai}

Baterai (aki) atau akkumulator adalah alat yang digunakan untuk menyimpan energi listrik agar sewaktu - waktu dapat kita pergunakan.

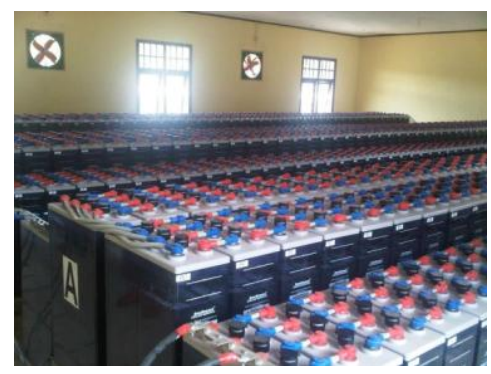

Gambar 2.5 Baterai

\section{Inverter}

Inverter adalah perangkat elektrik yang digunakan untuk mengubah arus listrik searah (DC) menjadi arus listrik bolak balik (AC). Inverter mengonversi DC dari perangkat seperti baterai, panel surya / solar cell menjadi AC. Penggunaan inverter dalam Pembangkit Listrik Tenaga Surya (PLTS) adalah untuk perangkat yang menggunakan AC (Alternating Current). Tegangan keluarannya dapat tetap atau variabel dengan frekuensi yang tetap atau variabel pula.

Tegangan keluaran variabel dapat ditentukan dengan mengubah tegangan masukan DC-nya, dimana dalam hal ini penguatan dari inverter dijaga untuk tetap konstan. Dalam perkembangan teknologi, ada beberapa inverter yang memiliki konsep MPPT (Maximum Power Point Tracking), dimana inverter mampu menaikkan tegangan input menjadi titik tertinggi untuk menghasilkan daya output yang maksimal.

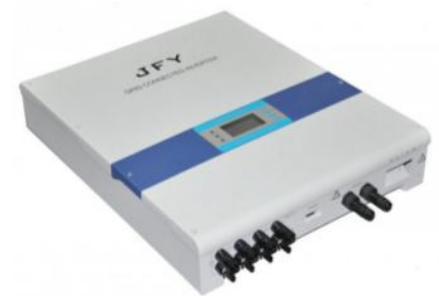

Gambar 2.6 Inverter dengan MPPT

\subsection{Jenis-jenis Sistem PLTS}

1. Stand Alone System

Stand Alone System atau Sistem Pembangkit Listrik Tenaga Surya Terpusat (PLTS-Terpusat) merupakan sistem pembangkit listrik alternatif untuk daerah-daerah terpencil/pedesaan yang tidak terjangkau oleh jaringan PLN.

Sistem PLTS-Terpusat yaitu sistem pembangkit yang hanya mengandalkan energi matahari sebagai satu-satunya sumber unergi utama dengan menggunakan rangkaian fotovoltaik modul untuk menghasilkan energi listrik sesuai dengan kebutuhan.

Secara umum konfigurasi PLTSTerpusat dapat dilihat seperti terlihat blok diagram dibawah :

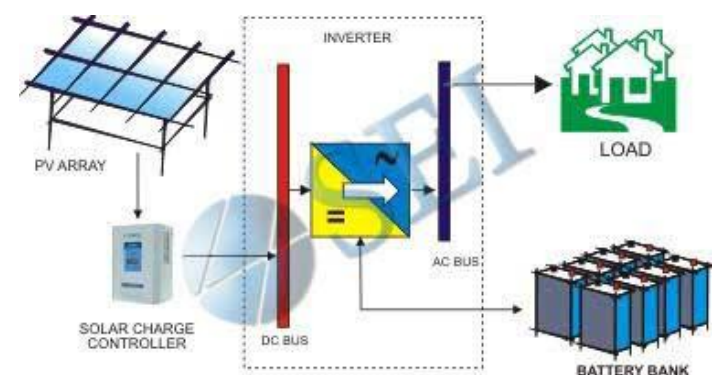

Gambar 2.7 Prinsip kerja PLTS-Terpusat 


\section{On grid}

Grid Connected PV System merupakan solusi Green Energy bagi penduduk perkotaan baik perumahan ataupun perkantoran. Sistem ini akan mengurangi tagihan listrik rumah tangga dan memberikan nilai tambah pada pemiliknya.

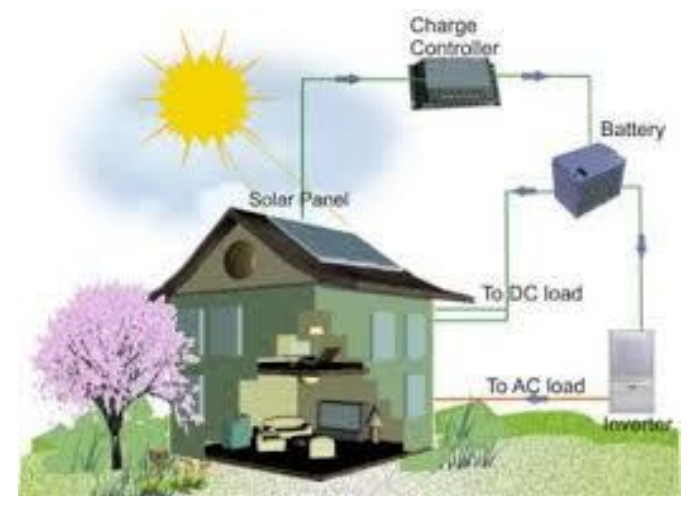

Gambar 2.8 Sistem On grid

3. Hybrid Power System

Sistem ini merupakan salah satu alternatif sistem pembangkit yang tepat diaplikasikan pada daerahdaerah yang sukar dijangkau oleh pembangkit besar seperti jaringan PLN atau PLTD. PLTH ini memanfaatkan renewable energy sebagai sumber utama (primer) yang dikombinasikan dengan diesel Generator sebagai sumber energi cadangan (sekunder).

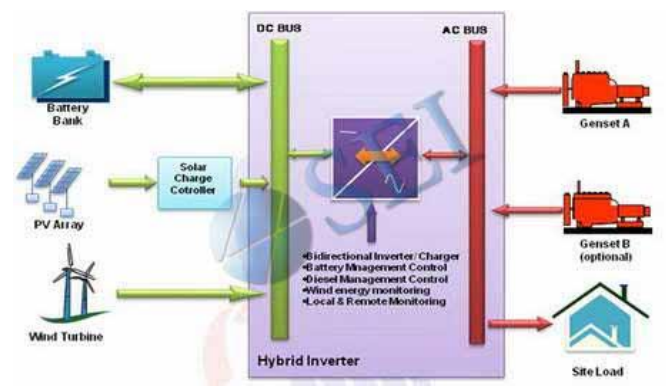

Gambar 2.9 Sistem PLTH Surya, Angin, Diesel

\section{METODE PENELITIAN}

\subsection{Analisa Kebutuhan}

Penggunaan PLTS pada stasiun kereta api bertujuan agar mampu menopang atau mengganti peran PLN sebagai penyuplai listrik. Karena penggunaan PLTS sebagai penyedia listrik mandiri merupakan sarana investasi yang menguntungkan stasiun kereta api. PLTS juga sebagai bentuk investasi jangka panjang, ditambah dengan biaya perawatan PLTS yang murah, akan menguntungkan bagi setiap stasiun kereta api yang menggunakannya. Untuk lebih jelasnya, sistem PLTS pada stasiun kereta api dapat dilihat pada blok diagram berikut ini.

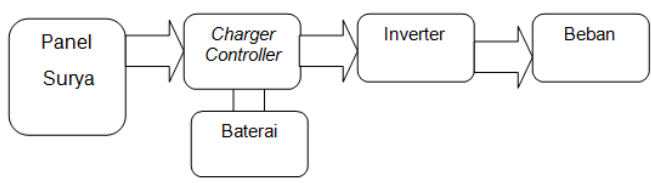

Gambar 3.1 Blok Diagram Sistem PLTS

Data harga listrik PLN :

Tabel 3.1 Data harga listrik PLN

PT PLN (Persero)

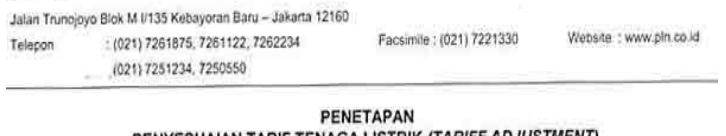
PENYESUAIAN TARIF TENAGA LISTRIK (TARIFF ADJUSTMENT) BULAN FEBRUARI\& MARET 2017

\begin{tabular}{|c|c|c|c|c|c|c|}
\hline \multirow[b]{2}{*}{ no. } & \multirow[b]{2}{*}{ GOL. TARIF } & \multirow[b]{2}{*}{ BATAS DAYA } & \multicolumn{3}{|c|}{ REGULER } & \multirow{2}{*}{$\begin{array}{c}\text { PRA BAYAR } \\
\text { (RQNWM) }\end{array}$} \\
\hline & & & $\begin{array}{l}\text { BiAYA BEBAN } \\
\text { (ReNNADuan) }\end{array}$ & \multicolumn{2}{|c|}{ 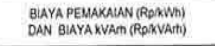 } & \\
\hline$\frac{1}{2}$ & $\frac{R \cdot R \cdot \pi R}{R \cdot T R}$ & $\frac{1300 \mathrm{VA}}{2000 \mathrm{VA}}$ & $\div$ & \multicolumn{2}{|c|}{$\begin{array}{l}.46728 \\
1.67728 \\
\end{array}$} & $\frac{1.65728}{1.46728}$ \\
\hline 3 & $R \cdot 2 \pi R$ & $\begin{array}{l}3.500 \mathrm{VA} \\
50.5500 \mathrm{VA}\end{array}$ & $\cdot 1$ & \multicolumn{2}{|r|}{1.467 .28} & 1.66728 \\
\hline 4. & $R \cdot 3 T R$ & $\frac{6000 \mathrm{VA}}{6 \mathrm{~s}}$ & •) & \multicolumn{2}{|r|}{$1.467,28$} & $1.467,28$ \\
\hline 5 & $B \cdot 2 \pi R$ & $\begin{array}{l}66000 \mathrm{VA} \\
\text { so. } 200 \mathrm{kVA}\end{array}$ & •) & \multicolumn{2}{|r|}{1.467 .28} & 1.457 .28 \\
\hline 6 & B $3 \mathrm{TM}_{\mathrm{M}}$ & $\begin{array}{l}\text { di itas } \\
200 \mathrm{kVA}\end{array}$ & ") & $\begin{array}{l}\text { Blok WGP } \\
\text { Blok KWBP } \\
\text { kVATh }\end{array}$ & 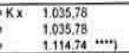 & . \\
\hline 7. & $1.37 \mathrm{M}$ & $\begin{array}{l}\text { di atas } \\
200 \mathrm{kVA}\end{array}$ & ") & 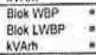 & 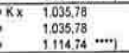 & . \\
\hline 8. & $14 \pi$ & 30.000 KVA ke atas & $\cdots)$ & 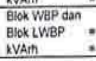 & $\quad 99674 \ldots$ & - \\
\hline 9. & P. $\rightarrow \pi R$ & $\begin{array}{l}6.6000 \mathrm{VA} \\
\text { id. } 200 \mathrm{NVA}\end{array}$ & $\cdot 1$ & \multicolumn{2}{|c|}{1.467 .28} & 1.6728 \\
\hline 10. & P.2TM & $\begin{array}{l}\text { ciotas } \\
200 \mathrm{kVA}\end{array}$ & *) & $\begin{array}{l}\text { Blox WEP } \\
\text { Blok LWBP : } \\
\text { WATh }\end{array}$ & 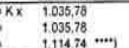 & . \\
\hline$\frac{11 .}{12}$ & $\frac{p, 3 T R}{U T R T M T}$ & & 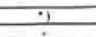 & \multicolumn{2}{|r|}{$\frac{166728}{164452}$} & 1.45728 \\
\hline
\end{tabular}

Data harga energi surya oleh pemerintah :

Tabel 3.2 Data harga energi surya oleh pemerintah

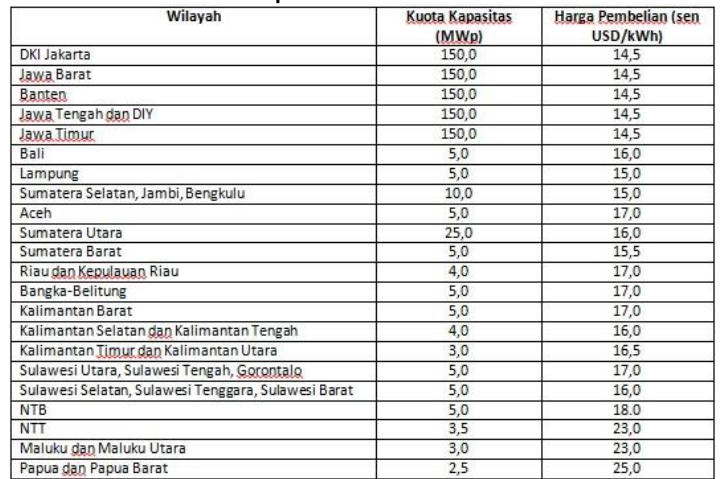




\subsection{Perancangan Penelitian \\ 3.2.1.Profil Stasiun Kereta Api Cirebon Prujakan}

Stasiun Cirebon Prujakan (CNP), dahulu disebut Station Cheribon Proedjakan atau Stasiun Cheribon SCS, adalah stasiun kereta api kelas ekonomi di Kota Cirebon. Stasiun ini terletak pada ketinggian +4 meter; berada di Jalan kembar/Jalan Nyi Mas Gandasari, Kelurahan Pekalangan,Kecamatan Pekali pan, Kota Cirebon. Stasiun ini merupakan stasiun besar yang ada di daerah operasi III Cirebon, selain stasiun Cirebon dan stasiun Jatibarang.

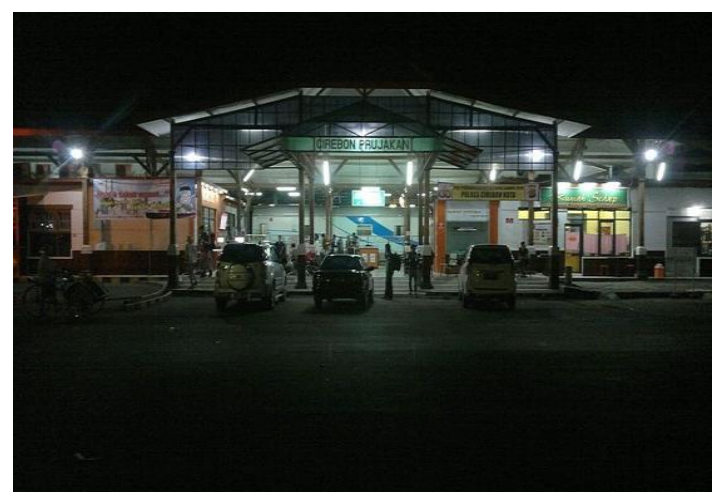

Gambar 3.2 Pintu masuk stasiun kereta api Cirebon Prujakan

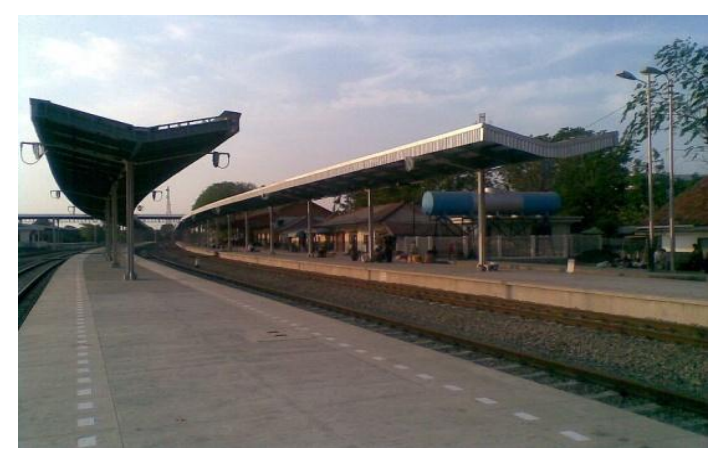

Gambar 3.3 Tampak peron stasiun kereta api Cirebon Prujakan

\subsubsection{Kondisi Kelistrikan}

Stasiun Cirebon Prujakan merupakan sebuah stasiun kereta api yang terletak di Kelurahan Pekalangan, Kecamatan Pekalipan, Kota Cirebon. Stasiun Cirebon Prujakan merupakan stasiun pemberhentian bagi kereta api ekonomi dengan tujuan Jakarta dan kota-kota di bagian tengah-timur Pulau Jawa (kecuali KA Jayabaya dan Krakatau). Untuk kereta api kelas eksekutif, bisnis, dan campurannya tidak berhenti di stasiun ini, melainkan berhenti di Stasiun Cirebon.

Pada bulan Juli 2011 Stasiun Cirebon Prujakan direnovasi dan ditinggikan peronnya, serta ditambah jalur dari yang semula 5 jalur menjadi 9 jalur. Empat jalur menuju Tegal-Pekalongan-SemarangSurabaya, empat jalur lagi menuju Purwokerto-Kroya-Yogyakarta-Solo, dan satu jalur khusus untuk kereta api barang. Sehingga, kereta kelas ekonomi tak perlu berhenti di Stasiun Cirebon, namun berhenti di Stasiun Cirebon Prujakan. Stasiun ini adalah satu-satunya stasiun kereta api di Daop 3 Cirebon yang memiliki sistem ticketting drive thru.

Pada Stasiun kereta api Cirebon Prujakan memiliki beberapa ruangan, diantaranya ada PPKA, ruang staf dan loket, mushola, toilet, ruang kepala stasiun dan peron. Terdapat 9 peron yang masing-masing memiliki luas $2 \times 200 \mathrm{~m}$. Data diperoleh dengan cara melakukan pengukuran langsung ke lokasi penelitian. Data yang dikumpulkan adalah besar daya yang digunakan peralatan listrik yang hanya digunakan untuk keperluan berlangsungnya kegiatan utama stasiun. Data-data tersebut antara lain :

Tabel 3.3 Peralatan Listrik

\begin{tabular}{|c|c|c|}
\hline No & Peralatan & $\begin{array}{c}\text { Besar Daya } \\
\text { (Watt) }\end{array}$ \\
\hline \multirow{5}{*}{1} & \multicolumn{2}{|c|}{ Loket } \\
\hline & 2 Unit Komputer & 240 \\
\hline & 2 Unit Mesin Tiket & 20 \\
\hline & $1 \mathrm{AC}$ & 800 \\
\hline & Lampu LED $2 \times 5$ Watt & 10 \\
\hline \multirow{4}{*}{2} & \multicolumn{2}{|c|}{ Ruang Announcer } \\
\hline & 1 Unit Komputer & 120 \\
\hline & $1 \mathrm{AC}$ & 800 \\
\hline & 1 Lampu LED & 5 \\
\hline 3 & E-ticketting & 880 \\
\hline \multirow{2}{*}{4} & \multicolumn{2}{|c|}{ Peron $1 \mathrm{~s} / \mathrm{d} 9$} \\
\hline & Lampu 225 x 20 Watt & 4500 \\
\hline \multicolumn{2}{|r|}{ Total } & 7375 \\
\hline 5 & PPKA & 3260 \\
\hline 6 & Ruang Kepala Stasiun & 1300 \\
\hline 7 & Ruang Staf & 1300 \\
\hline 8 & Mushola & 140 \\
\hline 9 & Toilet & 1220 \\
\hline 10 & Lain-lain & 395 \\
\hline \multicolumn{2}{|r|}{ Total } & 14990 \\
\hline
\end{tabular}

Berdasarkan Tabel 3.1, besar daya minimum untuk kegiatan utama stasiun adalah $7,375 \mathrm{~kW}$. Sedangkan besar daya keseluruhan stasiun adalah 14,99 kW. Yang mana kelistrikan stasiun PLN disuplai oleh PLN tegangan 220/380 
dengan menggunakan penghantar 3 fasa 5 kawat (fasa R, fasa S, fasa T, kawat Netral dan Grounding) yang dialiri oleh arus masing-masing fasa sebesar 20 Ampere.

\subsubsection{Menentukan Spesifikasi Komponen}

1. Panel Surya

Pada perancangan PLTS ini, panel surya yang digunakan adalah produksi PT. Len tipe monokristalin berkapasitas $200 \mathrm{Wp}$; $24 \mathrm{~V}$. Pemilihan panel surya tipe ini karena telah diuji dan disertifikasi oleh lembaga B2TKE-BPPT berdasarkan SNI: 04-3580.2-1995, sehingga kualitasnya terjamin. Panel surya yang diuji menurut Standard Test Condition (STC) memiliki spesifikasi sebagai berikut :

Tabel 3.4 Karakterisitik Kelistrikan Panel Surya

\begin{tabular}{|l|r|}
\hline $\begin{array}{l}\text { Optimum Operating Volatge } \\
\text { (Vmp) }\end{array}$ & $37,44 \mathrm{~V}$ \\
\hline Optimum Operating Current (Imp) & $5,35 \mathrm{~A}$ \\
\hline Open Circuit Voltage (Voc) & $45,5 \mathrm{~V}$ \\
\hline Short Circuit Current (IsC) & $5,8 \mathrm{~A}$ \\
\hline Maximum Power at STC (Pmax) & $200 \mathrm{Wp}$ \\
\hline Modul Efficiency & $16 \%$ \\
\hline Operating Module Temperature & $-40^{\circ} \mathrm{C}$ to \\
$85^{\circ} \mathrm{C}$ \\
\hline Maximum System Voltage & $1000 \mathrm{Vdc}$ \\
\hline Maximum Series Fuse Rating & $20 \mathrm{~A}$ \\
\hline Power Tolerance & $0-3 \%$ \\
\hline
\end{tabular}

\section{STC = Irradiance $1000 \mathrm{~W} / \mathrm{m}^{2}$; Module themperature $25^{\circ} \mathrm{C} ; \mathrm{AM}=1,5$}

Tabel 3.5 Karakterisitik Mekanik Panel Surya

\begin{tabular}{|l|r|}
\hline Modul Type & Monocrystalline \\
\hline Number of cells & $72(6 \times 12) \mathrm{cm}$ \\
\hline Dimensions & $1580 \times 808 \times 45 \mathrm{~mm}$ \\
\hline Weight & $16 \mathrm{~kg}$ \\
\hline Junction Box & IP65 \\
\hline Diodes & $\begin{array}{r}\text { Schotkky bypass } \\
\text { diode }\end{array}$ \\
\hline
\end{tabular}

Faktor-faktor yang mempengaruhi kinerja panel surya antara lain sebagai berikut.
1) Suhu modul

Sebuah panel surya dapat beroperasi secara maksimal jika suhu panel tetap normal pada suhu $25^{\circ} \mathrm{C}$. Kenaikan suhu lebih tinggi dari suhu normal pada panel surya akan melemahkan tegangan open circuit (Voc) yang dihasilkan. Setiap kenaikan suhu surya $1^{\circ} \mathrm{C}$ (dari $25^{\circ} \mathrm{C}$ ) akan mengakibatkan berkurangnya daya yang dihasilkan sekitar 0,5\% (Schaeer: 1990).

Menurut Dewa Ayu Sri (2011), menghitung besarnya daya yang berkurang pada saat suhu di sekitar panel mengalami kenaikan ${ }^{\circ} \mathrm{C}$ dari suhu standar, menggunakan persamaan:

$$
\begin{gathered}
P_{\text {saqt t }} \text { naik }{ }^{\circ} \mathrm{C} \\
\text { (3.1) }
\end{gathered}
$$

Dimana:

$$
\begin{aligned}
& \mathrm{P}_{\text {saat t naik }}{ }^{\circ} \mathrm{C} \text { : daya pada saat suhu naik }{ }^{\circ} \mathrm{C} \\
& \text { dari suhu standar } \\
& P_{M P P} \quad \text { : daya keluaran maksimal } \\
& \text { modul surya } \\
& \Delta \mathrm{t} \quad \text { : kenaikan suhu }
\end{aligned}
$$

Daya keluaran maksimum panel surya pada saat suhu naik menjadi $t{ }^{\circ} \mathrm{C}$ dari suhu standar dihitung dengan persamaan:

$P_{M P P \text { saat naik menjadi }{ }^{\circ} \mathrm{C}}=P_{M P P}-$

$P_{\text {saat t naik }{ }^{\circ} \mathrm{C}}{ }^{[2]}$

$\mathrm{P}_{\text {MPP }}$ saat $\mathrm{t}$ naik menjadi $\mathrm{t}^{\circ} \mathrm{C}$ adalah daya keluaran maksimum panel surya pada saat suhu di sekitar panel naik menjadi $t{ }^{\circ} \mathrm{C}$ dari suhu standar. Faktor koreksi temperatur (Themperatur Correction Factor) dihitung dengan rumus:

${ }^{[3]} \mathrm{TCF}=\frac{P_{M P P \text { saat naik menjadi }{ }^{\circ} \mathrm{C}}}{P_{M P P}}$

2) Intensitas Cahaya Matahari

Radiasi matahari di bumi pada lokasi yang berbeda akan bervariasi dan sangat bergantung dengan keadaan spektrum matahari ke bumi. Radiasi matahari akan berpengaruh terhadap daya yang dikeluarkan oleh panel.

3) Kecepatan tiupan angin

Kecepatan tiupan angin di sekitar lokasi panel surya akan sangat memantu terhadap pendinginan suhu permukaan panel sehingga suhu dapat terjaga di kisaran suhu yang kondusif. 
4) Keadaan atmosfir bumi

Keadaan atmosfir bumi berawan, mendung, jenis debu udara, asap, uap air, kabut dan polusi sangat menentukan kinerja dari panel surya.

5) Peletakan panel surya

(Dewa Ayu Sri, 2011) Agar energi matahari yang diserap berada pada nilai yang optimal maka permukaan panel surya harus dipertahankan tegak lurus terhadap sinar matahari yan jatuh ke permukaan panel surya. Oleh karena itu peletakan panel surya sangat penting agar kinerja panel surya maksimal.

\section{Charge Controller}

Charge Controller yang digunakan untuk sistem PLTS ini adalah produksi LEONICS dengan tipe SCB-48120 yang memiliki kelebihan sebagai berikut :

a. Mampu mengatur pengisian baterai sehingga menghindari overcharging dan overvoltage.

b. Mampu mengatur arus yang dibebaskan dari baterai untuk mencegah terjadinya overloading pada baterai.

c. Dapat memonitoring suhu baterai.

Dengan spesifikasi antara lain:

Tabel 3.6 Spesifikasi Charge Controller LEONICS SC-48120

\begin{tabular}{|l|r|}
\hline Capacity & $6,6 \mathrm{~kW}$ \\
\hline Vmp of PV & $64-128 \mathrm{Vdc}$ \\
\hline Voc & $<145 \mathrm{Vdc}$ \\
\hline Charging Current & $120 \mathrm{~A}$ \\
\hline Nominal Battery Voltage & $48 \mathrm{Vdc}$ \\
\hline Charge Peak Efficiency & $99 \%$ \\
\hline Dimension & $50 \times 64 \times 26,6 \mathrm{~cm}$ \\
\hline Weight & $42 \mathrm{~kg}$ \\
\hline
\end{tabular}

\section{Baterai}

Baterai yang digunakan untuk sistem perencanaan ini adalah tipe Lead-acid, deep-cycle. Pemilihan tipe baterai tersebut, karena memiliki efisiensi yang tinggi dan umur yang relatif lebih lama dibandingkan tipe baterai lainnya. Tipe ini juga lebih tahan terhadap siklus pengisian-pengosongan baterai yang berulang-ulang, sehingga cocok untuk penggunaan proyek energi alternatif jangka lama seperti PLTS. Berikut adalah tabel mengenai perbedaan tipe-tipe baterai.

Tabel 3.7 Perbedaan Tipe Baterai

\begin{tabular}{|c|c|c|c|c|c|}
\hline \multirow[b]{2}{*}{ Battery Type } & \multirow{2}{*}{$\begin{array}{c}\text { Max } \\
D O D \\
(\%)\end{array}$} & \multirow{2}{*}{$\begin{array}{l}\text { Cycle Life } \\
\text { (cycles) }\end{array}$} & \multirow{2}{*}{$\begin{array}{c}\text { Calendar } \\
\text { Life } \\
\text { (years } \\
\text { ) }\end{array}$} & \multicolumn{2}{|c|}{ Efficiencies } \\
\hline & & & & $A h$ & Wh \\
\hline Lead-acid, SLI & 20 & 500 & $1-2$ & 90 & 75 \\
\hline Lead-acid, golf cart & 80 & 1000 & $3-5$ & 90 & 75 \\
\hline $\begin{array}{l}\text { Lead-acid, deep- } \\
\text { cycle }\end{array}$ & 80 & 2000 & $7-10$ & 90 & 75 \\
\hline Nikel-Cadmium & 100 & $1000-2000$ & $10-15$ & 70 & 60 \\
\hline Nikel-metal hydride & 100 & $1000-2000$ & $8-10$ & 70 & 65 \\
\hline
\end{tabular}

Baterai yang digunakan untuk rancangan sistem PLTS ini memiliki spesifikasi sebagai berikut.

Tabel 3.8 Spesifikasi Baterai

\begin{tabular}{|l|r|}
\hline Type & Double Tech OPzV-2-1000 \\
\hline Capacity & $1000 \mathrm{Ah}$ \\
\hline Weight & $70 \mathrm{~kg}$ \\
\hline Dimension & $233 \times 210 \times 646 \mathrm{~mm}$ \\
\hline
\end{tabular}

4. Inverter

Inverter yang digunakan untuk rancangan sistem PLTS ini adalah produksi LEONICS dengan tipe Apollo S219 memiliki spesifikasi sebagai berikut :

Tabel 3.9 Spesifikasi Inverter

\begin{tabular}{|l|r|}
\hline Rated Power & $5 \mathrm{~kW}$ \\
\hline Nominal Voltage & $48 \mathrm{~V}$ \\
\hline Efficiency & $98 \%$ \\
\hline Dimensions & $60 \times 105 \times 46 \mathrm{~cm}$ \\
\hline Weight & $45 \mathrm{G}$ \\
\hline
\end{tabular}

\subsection{Teknik Analisis}

\subsubsection{Menghitung Area Array (PV Area)}

Luas area array diperhitungkan dengan menggunakan rumus sebagai berikut :

$$
P V_{\text {Area }}={\frac{W}{G_{a v} \times \eta_{p v} \times T C F \times \eta_{\text {out }}}}^{[1]}
$$

(Sumber: buku skripsi Ismu Hajar, Teknik Elektro STT-PLN 2015)

Dimana :

$$
\begin{aligned}
P V_{\text {Area }}= & \text { Luas area array }\left(\mathrm{m}^{2}\right) \\
W= & \text { Besar pemakaian energi listrik } \\
& (\mathrm{kWh}) \\
G_{a v}= & \begin{array}{l}
\text { Nilai isolasi harian Matahari } \\
\left(\mathrm{kWh} / \mathrm{m}^{2}\right)
\end{array}
\end{aligned}
$$


Yaitu daya per unit yang dihasilkan matahari dalam bentuk radiasi elektromagnet per meter persegi

$\eta_{p v}=$ Efisiensi modul surya (\%)

TCF = Temperature Correction Factor

$\eta_{\text {out }}=$ effisiesnsi output $(\%)$

\subsubsection{Menghitung Daya yang Dibangkitkan PLTS (Watt-peak)}

Dari perhitungan area array, maka besar daya yang dibangkitkan PLTS (Watt Peak) dapat dihitung dengan rumus sebagai berikut :

$P$ Watt peak $=$ area array $\times P S I \times \eta_{P V}{ }^{[1]}$

(Sumber: buku skripsi Ismu Hajar, Teknik Elektro STT-PLN 2015)

Dimana :

$\mathrm{P}_{\text {wattpeak }}=$ Besar daya yang dibangkitkan PLTS (Wattpeak)

PSI = Peak Sun Insolation (PSI) adalah $1000 \mathrm{~W} / \mathrm{m}^{2}$

\subsubsection{Menghitung Jumlah Panel Surya}

Dalam menentukan jumlah panel surya yang akan digunakan, ditentukan dengan rumus sebagai berikut.

Jumlah Panel Surya $=\frac{P_{\text {Watt peak }}}{P_{M P P}}$

(Sumber: buku skripsi Ismu Hajar, Teknik Elektro STT-PLN 2015)

Dimana :

$\mathrm{P}_{\mathrm{MPP}}=$ Daya maksimum panel surya yang digunakan (W)

$\mathrm{P}_{\text {Wattpeak }}=$ Daya yang dibangkitkan $(\mathrm{Wp})$

Untuk memperoleh besar tegangan, arus dan daya yang sesuai dengan kebutuhan, maka panel-panel surya tersebut harus dikombinasikan secara seri dan paralel dengan aturan sebagai berikut:

1) Untuk memperoleh tegangan keluaran yang lebih besar dari tegangan keluaran panel surya, maka dua buah (lebih) panel surya dihubungkan secara seri.

2) Untuk memperoleh arus keluaran yang lebih besar dari arus keluaran panel surya, maka dua buah (lebih) panel surya dihubungkan secara paralel.

3) Untuk memperoleh daya keluaran yang lebih besar dari daya keluaran panel surya dengan tegangan yang konstan maka panel-panel surya dihubungkan secara seri dan paralel.

\subsubsection{Menghitung Kapasitas Baterai}

Satuan energi (dalam WH) dikonversikan menjadi Ah yang sesuai dengan satuan kapasitas baterai sebagai berikut.

$C=\frac{W \times A D}{(D O D \times V S)}[1]$

(Sumber: buku skripsi Ismu Hajar, Teknik Elektro STT-PLN 2015)

Dimana :

C = Kapasitas baterai yang dibutuhkan (Ah)

DOD $($ Deep of Discharge $)=$ Kedalaman kapasitas yang dapat diambil dari baterai

$\mathrm{AD}=$ Autonom Days (Hari Otonomi)

$\mathrm{V}_{\mathrm{s}} \quad=$ Tegangan Sistem

\subsubsection{Menentukan Kapasitas Charge Controller}

Kapasitas charge controller ditentukan berdasarkan daya maksimal yang mampu dibangkitkan array surya serta arus yang keluar dari array tersebut. $\mathrm{Hal}$ ini agar charge controller tetap mampu menyalurkan daya maksimal yang dibangkitkan serta tahan terhadap arus yang keluar dari array surya.

\subsubsection{Menentukan Kapasitas Inverter}

Spesifikasi inverter disesuaikan dengan charge controller yang digunakan. Tegangan masuk (input) dan tegangan keluar (output) dari inverter diketahui berdasarkan tegangan sistem dan nominal tegangan AC yang digunakan, yakni 220 Volt.

\section{HASIL DAN PEMBAHASAN}

4.1. Analisa Teknik

4.1.1. Kebutuhan Listrik Beban AlatAlat Yang Penting

4.1.1.1. Menghitung area Array (PV area)

Luas array yang dibutuhkan dihitung dengan rumus:

$$
P V_{\text {Area }}=\frac{W}{G_{a v} \times \eta_{p v} \times T C F \times \eta_{\text {out }}}
$$


Dimana :

$P V_{\text {Area }}=$ Luas area array $\left(\mathrm{m}^{2}\right)$

$W=$ Besar pemakaian energi listrik $(k W h)$

$G_{a v}=$ Nilai isolasi harian Matahari $\left(\mathrm{kWh} / \mathrm{m}^{2}\right)$

$\eta_{p v}=$ Kompensasi rugi-rugi instalasi PV array (\%)

$T C F=$ Themperature Correction Factor

$\eta_{\text {out }}=$ efisiensi output (\%)

Berdasarkan perkiraan beban harian, listrik di stasiun kereta api Cirebon Prujakan menyuplai selama 24 jam. Adapun daya yang dibutuhkan stasiun sebesar 7,375 kW, maka energi yang dibutuhkan stasiun sebesar 177 kWh Untuk nilai isolasi harian matahari (Gav) digunakan nilai isolasi rata-rata wilayah provinsi DKI Jakarta (Tabel 4.1), sebesar $4,97 \mathrm{kWh} / \mathrm{m}^{2}$.

Tabel 4.1 Radiasi Matahari provinsi Jawa Barat tahun 2016

\begin{tabular}{|c|c|}
\hline Bulan & $\begin{array}{c}\text { Daily Solar } \\
\text { Radiatio } \\
\mathrm{n} \\
\left(\mathrm{kWh} / \mathrm{m}^{2}\right)\end{array}$ \\
\hline Januari & 4,56 \\
\hline Februari & 4,67 \\
\hline Maret & 4,84 \\
\hline April & 4,94 \\
\hline Mei & 4,96 \\
\hline Juni & 5 \\
\hline Juli & 5,08 \\
\hline Agustus & 5,2 \\
\hline September & 5,4 \\
\hline Oktober & 5,4 \\
\hline November & 4,85 \\
\hline Desember & 4,72 \\
\hline Rata-rata & 4,97 \\
\hline
\end{tabular}

\section{Radiasi Matahari} $\left(\mathrm{kWh} / \mathrm{m}^{2}\right)$

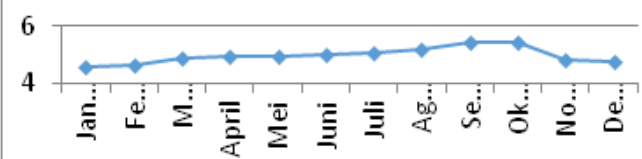

Gambar 4.1 Grafik Radiasi Matahari Daerah Jawa Barat
Tabel 4.2 Suhu Udara Jawa Barat Tahun 2016

\begin{tabular}{|r|l|r|r|r|}
\hline \multirow{2}{*}{ No. } & \multirow{2}{*}{ Bulan } & \multicolumn{3}{|c|}{ Suhu $\left(^{\circ} \mathbf{C}\right)$} \\
\cline { 3 - 5 } & & Minimum & Maksimum & Rata-rata \\
\hline 1 & Januari & 24,2 & 30,5 & 27,3 \\
\hline 2 & \multirow{2}{*}{ Pebruari } & 24,5 & 32,0 & 28,2 \\
\hline 3 & Maret & 25,5 & 33,2 & 29,3 \\
\hline 4 & April & 28,6 & 32,8 & 30,7 \\
\hline 5 & Mei & 28,6 & 32,6 & 30,6 \\
\hline 6 & Juni & 25,5 & 32,5 & 29,0 \\
\hline 7 & Juli & 23,6 & 30,8 & 27,2 \\
\hline 8 & Agustus & 25,2 & 33,1 & 29,1 \\
\hline 9 & September & 25,5 & 33,3 & 29,4 \\
\hline 10 & Oktober & 25,0 & 33,0 & 29,0 \\
\hline 11 & November & 25,3 & 32,8 & 29,0 \\
\hline 12 & Desember & 24,8 & 31,3 & 28,0 \\
\hline
\end{tabular}

Dan berdasarkan data BMKG, pada tahun 2016 suhu tertinggi daerah Jawa Barat terjadi pada bulan September, yaitu mencapai $33,3{ }^{\circ} \mathrm{C}$. Sedangkan suhu minimum terjadi pada bulan Juli yaitu 23,6 ${ }^{\circ} \mathrm{C}$. Berdasarkan spesifikasi modul surya (Tabel 3.1), modul surya memiliki kapasitas $200 \mathrm{Wp}$ dengan efisiensi modul sebesar $16 \%$. Maka besarnya daya yang berkurang saat suhu di sekitar panel surya mengalami kenaikan $8,3^{\circ} \mathrm{C}$ dari suhu standar $\left(25^{\circ} \mathrm{C}\right)$ dihitung dengan menggunakan persamaan (3.1).

$$
\begin{aligned}
P_{\text {saat t naik } 8,3^{\circ} \mathrm{C}} & \\
& =0.5 \% \text { per }^{\circ} \mathrm{C} \times P_{M P P} \\
& \times \Delta T\left({ }^{\circ} \mathrm{C}\right) \\
& =0.5 \% \mathrm{per}^{\circ} \mathrm{C} \times 200 \mathrm{~W} \\
& \times 8,3^{\circ} \mathrm{C} \\
& =8,3 \mathrm{~W}
\end{aligned}
$$

Untuk daya keluaran maksimum modul surya pada saat suhu naik menjadi 33,3 ${ }^{\circ} \mathrm{C}$, dihitung dengan menggunakan persamaan (3.2)

$$
\begin{aligned}
P_{M P P \text { saat naik menjadi }{ }^{\circ} \mathrm{C}} & \\
= & P_{M P P}-P_{\text {saat } t \text { naik }}{ }^{\circ} \mathrm{C} \\
P_{M P P \text { saat } t=33,3^{\circ} \mathrm{C}} & =200 \mathrm{~W}-8,3 \mathrm{~W} \\
& =191,7 \mathrm{~W}
\end{aligned}
$$

Berdasarkan hasil perhitungan daya keluar maksimum modul surya pada saat suhu naik menjadi $33,3^{\circ} \mathrm{C}$, maka nilai TCF dapat dihitung dengan menggunakan persamaan (3.3).

$$
\begin{gathered}
T C F=\frac{P_{M P P \text { saat naik menjadi } t^{\circ} \mathrm{C}}}{P_{M P P}} \\
T C F=\frac{191,7 \mathrm{~W}}{200 \mathrm{~W}} \\
=0,96
\end{gathered}
$$


Besar nilai efisiensi output ( $\left.\eta_{\text {out }}\right)$ ditentukan dengan nilai efisiensi inverter $(98 \%)$ dan efisiensi charge controller $(99 \%)$, maka besar nilai efisiensi output adalah 97\%. Maka, untuk memperoleh luas area PV array dengan cara mensubstitusikan nilai energi listrik yang dibutuhkan (W), isolasi rata-rata matahari $\left(\mathrm{G}_{\mathrm{AV}}\right)$, Efisiensi $\mathrm{P}_{\mathrm{PV}}\left(\eta_{p v}\right)$, dan efisiensi output $\left(\eta_{\text {out }}\right)$ ke persamaan (3.4).

$$
\begin{aligned}
& \text { PV Area } \\
& =\frac{177 \mathrm{kWh}}{4,97 \mathrm{kWh} / \mathrm{m}^{2} \times 0,16 \times 0,96 \times 0,97} \\
& =239 \mathrm{~m}^{2}
\end{aligned}
$$

\subsubsection{Menghitung Daya yang Dibangkitkan PLTS (Watt-peak)}

Dari perhitungan area array, maka besar daya yang dibangkitkan PLTS (Watt-peak) dapat dihitung dengan persamaan (3.5). Dengan area array adalah $239 \mathrm{~m}^{2}$, Peak Sun Insolation (PSI) adalah $1000 \mathrm{~W} / \mathrm{m}^{2}$ dan efisiensi modul surya adalah $16 \%$ maka :

$$
\begin{aligned}
& P(\text { Watt peak }) \\
& \quad=\text { area array } \times P S I \\
& \quad \times \eta_{P V} \\
& P(\text { Watt peak }) \\
& \quad=239 \mathrm{~m}^{2} \\
& \quad \times 1000 \mathrm{~W} / \mathrm{m}^{2} \times 0,16 \\
& \quad=38.240 \mathrm{Watt} \text { peak }
\end{aligned}
$$

\subsubsection{Menentukan Jumlah Modul Surya}

Modul surya yang akan digunakan pada perencanaan sistem ini memiliki kapasitas $\mathrm{P}_{\text {MPP }}$ sebesar $200 \mathrm{Wp}$ per modul. Berdasarkan nilai tersebut, maka jumlah modul surya yang dibutuhkan sistem ini dapat dihitung dengan menggunakan persamaan (3.6).

$$
\begin{gathered}
\text { Jumlah Panel Surya }=\frac{38.240 \mathrm{Wp}}{200 \mathrm{Wp}} \\
=191,2 \approx 192 \text { panel surya }
\end{gathered}
$$

1. Desain Panel Surya

Modul surya yang digunakan merupakan produksi dari PT. Len (Persero) dengan tipe monokristalin 200 Wp;24V dengan spesifikasi nilai $\mathrm{V}_{\mathrm{mp}}=$ 37,44 $\mathrm{V}$ dan $\mathrm{I}_{\mathrm{mp}}=$ 5,35 $\mathrm{A}$, dan 192 panel surya tersebut akan disusun menjadi rangkaian panel surya atau array dengan rating tegangan sistem $48 \quad \mathrm{~V}$ dan disesuaikan dengan rating charger controller di kisaran tegangan 64-128 $\mathrm{V}_{\mathrm{dc}}$. Maka, panel yang terpasang seri sebanyak 2 panel dan yang dipasang paralel sebanyak 96 string. Sehingga array tersebut menghasilkan tegangan sebesar :

$$
\begin{aligned}
V m p \text { array } & =V m p \times 2 \\
& =37,44 \mathrm{~V} \times 2 \\
& =74,88 \mathrm{~V}
\end{aligned}
$$

Dan menghasilkan arus sebesar:

$$
\begin{aligned}
\operatorname{Imp} \text { array } & =\operatorname{Imp} \times 96 \\
& =5,35 A \times 96 \\
& =513,6 \mathrm{~A}
\end{aligned}
$$

Berdasarkan tabel 3.2, panel surya memiliki spesifikasi panjang $\times$ lebar yaitu $1,6 \mathrm{~m} \times 0,81 \mathrm{~m}=1,296 \mathrm{~m}^{2}$, luas daerah panel surya. Maka, luas array untuk 192 modul surya adalah 248,832 $\mathrm{m}^{2}$. Luas atap peron stasiun cukup untuk ditempati array tersebut, yakni $400 \mathrm{~m}^{2}$ per peron.

2. Pemasangan Panel Surya

Untuk mendapatkan energi matahari yang maksimum, maka orientasi pemasangan rangkaian panel surya (array) ke arah matahari adalah hal yang penting untuk diperhatikan. Letak geografis kota Cirebon Jawa Barat yang berada pada posisi $7^{\circ}$ LS dan $108^{\circ}$ BT (BPS Cirebon, 2010) menunjukkan bahwa wilayah Cirebon Jawa Barat berada di belahan bumi selatan. Berdasarkan hal tersebut, maka pemasangan panel surya untuk PLTS yang akan dikembangkan di stasiun kereta api Cirebon Prujakan diorientasikan mengarah ke utara dan disarankan dengan sudut elevasi $10^{\circ}$. Hal tersebut peneliti telah melakukan simulasi di B2TKE-BPPT (memiliki derajat LS sama) terhadap penentuan sudut elevasi yang baik yang bertujuan agar hujan dan gaya gravitasi dapat menjaga panel surya tetap bersih, namun energi yang diserap tetap maksimal.

Tilt $10^{\circ}$

Gambar 4.3 llustrasi Orientasi Panel Surya 


\subsubsection{Menentukan Jumlah Charge Controller}

Kapasitas charge controller ditentukan berdasarkan besar daya maksimal yang mampu dihasilkan array surya, yakni sebesar $38,5 \mathrm{kWp}$ dan besarnya arus yang keluar dari array surya yaitu 513,6 A. Berdasarkan Tabel 3.3, charge controller memiliki kapasitas menyalurkan daya sebesar 6,6 kW, maka dari itu dibutuhkan 6 unit charge controller pada sistem perencanaan ini.

\subsubsection{Menentukan Jumlah Baterai}

Pada penelitian ini, kapasitas baterai ditentukan berdasarkan energi listrik yang dibutuhkan oleh stasiun selama 24 jam yaitu $177 \mathrm{kWh}$ dengan menggunakan persamaan (3.7). Hal-hal yang perlu diperhatikan untuk menentukan kapasitas baterai adalah:

1) DOD (Deep of Discharge), yaitu kedalaman kapasitas yang dapat digunakan pada baterai, yakni $80 \%$. DOD ini ditentukan oleh pabrik produksi baterai tersebut.

2) Autonom Days, yaitu parameter keadaan dimana lamanya (hari) jika cuaca buruk selama beberapa hari atau keadaan dimana energi matahari tidak maksimal, sehingga modul surya tidak memperoleh suplai energi yang cukup. Di Indonesia, penetapan hari otonomi adalah selama 3 hari.

3) Efisiensi Baterai, yaitu sebesar $98 \%$

Maka, besar kapasitas baterai yang dibutuhkan adalah:

$$
\begin{gathered}
C=\frac{177 \mathrm{kWh} \times 3}{0,8 \times 48 \mathrm{~V}} \mathrm{Ah} \\
=13828,1 \mathrm{Ah}: 0,98=14110 \mathrm{Ah}
\end{gathered}
$$

Baterai yang digunakan pada perencanaan sistem ini memiliki kapasitas 1000 Ah dan tegangan nominal $2 \mathrm{~V}$. Sehingga baterai harus dirangkai sedemikian rupa agar mengikuti tegangan sistem (48 V) dan besarnya nilai Ah. Jumlah baterai yang dipasang seri sebanyak 24 buah, dan susunan baterai yang dipasang paralel sebanyak:

$$
\begin{aligned}
\text { Susunan paralel } & =\frac{14110,2 \mathrm{Ah}}{1000 \mathrm{Ah}} \\
& =14,11 \approx 15
\end{aligned}
$$

Maka, jumlah baterai yang dibutuhkan untuk sistem ini sebanyak 360 buah.

\subsubsection{Menentukan Kapasitas Inverter}

Kapasitas inverter ditentukan dengan menyesuaikan kapasitas charge controller atau dipilih kapasitas inverter yang mampu menyuplai daya maksimal keluaran array surya sebesar $38,5 \mathrm{kWp}$. Berdasarkan Tabel 3.7, inverter yang dipilih memiliki kapasitas $5 \mathrm{~kW}$, maka jumlah inverter yang dibutuhkan untuk sistem perencanaan ini sebanyak 8 unit.

\subsection{Analisa Ekonomi}

\subsubsection{Kebutuhan Listrik Beban Alat-Alat Yang Penting}

\subsubsection{Investasi Awal}

Biaya investasi awal untuk PLTS yang akan dikembangkan di Stasiun kereta api Cirebon Prujakan mencakup biaya untuk komponen sistem PLTS serta biaya instalasinya. Tabel 4.3 menunjukkan

\begin{tabular}{|c|c|c|c|}
\hline KOMPONEN & JUMLAH & $\begin{array}{l}\text { HARGA } \\
\text { SATUAN } \\
\text { (Rp) }\end{array}$ & $\begin{array}{l}\text { TOTAL HARGA } \\
\text { (RP) }\end{array}$ \\
\hline $\begin{array}{l}\text { Panel Surya LEN } \\
200 \mathrm{Wp} ; 24 \mathrm{~V}\end{array}$ & 192 & 2.750 .000 & 520.000 .000 \\
\hline Inverter 5 kW & 8 & 12.670 .000 & 101.360 .000 \\
\hline $\begin{array}{l}\text { Charge Controller } \\
6,6 \mathrm{~kW}\end{array}$ & 6 & 3.250 .000 & 19.500 .000 \\
\hline Baterai $1000 \mathrm{Ah}$ & 360 & 1.716 .250 & 617.850 .000 \\
\hline \multicolumn{3}{|c|}{ Biaya Instalasi } & 20.000 .000 \\
\hline \multicolumn{3}{|c|}{ TOTAL } & 1.278 .710 .000 \\
\hline
\end{tabular}
besarnya biaya investasi awal yang akan dikeluarkan.

Tabel 4.3 Biaya Investasi Awal PLTS

\subsubsection{Biaya Pemeliharaan dan Operasional}

Biaya pemeliharaan dan operasional per tahun untuk PLTS dihitung sebesar $1 \%$ sampai $2 \%$ dari total biaya investasi awal (Santiari: 2011). Besar persentase tersebut mencakup biaya untuk pekerjaan pembersihan panel surya, biaya pemeliharaan serta pemeriksaan peralatan komponen. Adapun pada penelitian ini, biaya pemeliharaan dan operasional (M) ditetapkan sebesar $1 \%$ dari total biaya investasi awal. Hal itu karena Indonesia hanya memiliki 2 musim, yaitu musim hujan dan kemarau, dibandingkan negara lain yang memiliki 4 musim, sehingga biaya pemeliharaan dan operasionalnya lebih besar. Besarnya biaya tersebut per tahun adalah: 


$$
\begin{aligned}
M & =0,01 \times \text { Total biaya investasi } \\
& =0,01 \times R p .1 .278 .710 .000 \\
& =R p .12 .787 .100 / \text { tahun }
\end{aligned}
$$

\subsubsection{Menghitung Biaya Siklus Hidup PLTS (Life Cycle Cost)}

Biaya siklus hidup (LCC) pada sistem PLTS ditentukan oleh nilai sekarang dari biaya total sistem PLTS yang terdiri dari biaya investasi awal (C), biaya jangka panjang untuk pemeliharaan, operasional dan penggantian komponen $\left(\mathrm{M}_{\mathrm{pw}}\right)$.

PLTS yang akan dibangun pada penelitian ini, diasumsikan dapat beroperasi selama 25 tahun. Penentuan umur proyek ini mengacu kepada jaminan yang diberikan oleh produsen panel surya. Besarnya tingkat diskonto (i) yang digunakan untuk menghitung nilai sekarang pada penelitian ini adalah sebesar $11 \%$. Penentuan tingkat diskonto ini mengacu pada tingkat suku bunga kredit Bank Indonesia pada bulan Juli tahun 2016 yaitu rata-rata sebesar 11\% (BI, 2016).

Besarnya nilai sekarang (Present Value) untuk biaya pemeliharaan dan operasional $\left(\mathrm{M}_{\mathrm{pw}}\right)$ PLTS selama umur proyek 25 tahun dengan tingkat diskonto $11 \%$, dihitung dengan menggunakan persamaan berikut.

$$
\begin{gathered}
P=A\left[\frac{(1+i)^{n}-1}{i(1+i)^{n}}\right] \\
M p w(A 11 \% 25) \\
=R p .12 .787 .100\left[\frac{(1+0,11)^{25}-1}{0,11(1+0,11)^{25}}\right] \\
=R p .12 .787 .100 \times 8,4217 \\
=R p .107 .689 .120 \\
\approx R p .107 .689 .150
\end{gathered}
$$

Setelah memperoleh besar biaya pemeliharaan dan operasional $\left(M_{p w}\right)$, maka biaya siklus hidup (LCC) untuk PLTS yang akan dikembangkan selama umur proyek 25 tahun adalah sebagai berikut.

$$
\begin{aligned}
L C C & =C+M p w \\
& =1.278 .710 .000+107.689 .150 \\
& =R p .1 .386 .399 .150
\end{aligned}
$$

\subsubsection{Menghitung Biaya Energi PLTS (Cost of Energy)}

Menghitung biaya energi (cost of energy) suatu PLTS, ditentukan oleh biaya siklus hidup (LCC), faktor pemulihan modal (CRF) dan kWh produksi tahunan. Faktor pemulihan modal untuk mengkonversi semua arus kas biaya siklus hidup menjadi serangkaian biaya tahunan dihitung dengan persamaan sebagai berikut.

$$
\begin{aligned}
C R F & =\frac{\mathrm{i}(1+\mathrm{i})^{\mathrm{n}}}{(1+\mathrm{i})^{\mathrm{n}}-1} \\
& =\frac{0,11(1+0,11)^{25}}{(1+0,11)^{25}-1} \\
& =\frac{1,4944}{12,5855} \\
& =0,1187
\end{aligned}
$$

Sedangkan kWh produksi tahunan nilainya sebesar sebagai berikut.

$$
\begin{aligned}
A k W h= & k W h \text { produksi harian } \\
& \times 365 \\
= & 177 \times 365 \\
= & 64.605 \mathrm{kWh}
\end{aligned}
$$

Setelah memperoleh nilai LCC, CR dan $\mathrm{kWh}$ produksi tahunan, maka besar biaya energi (CoE) untuk perencanaan sistem PLTS ini adalah sebagai berikut.

$$
\begin{aligned}
\mathrm{CoE}= & \frac{\mathrm{LCC} \times \mathrm{CRF}}{\mathrm{A} \mathrm{kWh}} \\
& =\frac{1.386 .399 .150 \times 0,1187}{64.605} \\
& =R p .2 .547 \approx R p .2550 / \mathrm{kWh}
\end{aligned}
$$

\subsubsection{Analisis Kelayakan Investasi}

Kelayakan investasi PLTS ditentukan berdasarkan hasil perhitungan Net Present Value (NPV), Profitability Index (PI) dan Discounted Payback Period (DPP). Untuk menghitung kelayakan investasi PLTS digunakan biaya energi yaitu Rp. 2.550/kWh. Dengan biaya energi tersebut dan besar kWh produksi tahunan sebesar $64.605 \mathrm{kWh}$, maka arus kas masuk tahunannya adalah sebesar $\mathrm{Rp}$. 164.742.750. Sedangkan pengeluaran tahunannya diperhitungkan sebesar Rp. 12.787.100 yang ditentukan berdasarkan biaya pemeliharaan dan operasional tahunal PLTS. Tabel 4.4 menunjukkan hasil perhitungan arus kas bersih, faktor diskonto (i) sebesar $11 \%$ dan nilai sekarang arus kas bersih. Faktor diskonto (DF) dihitung dengan persamaan sebgai berikut. 


$$
D F=\frac{1}{(1+i)^{n}}
$$

Misalnya perhitungan faktor diskonto dengan $\mathrm{n}$ adalah tahun ke-1 adalah:

$$
\begin{aligned}
D F & =\frac{1}{(1+0,11)^{1}} \\
& =0,9009
\end{aligned}
$$

1. Net Present Value (NPV)

Teknik Net Present Value dihitung dengan menggunakan persamaan berikut.

$$
N P V=\sum_{t=1}^{n} \frac{N C F t}{(1+i)^{t}}-I A
$$

Tabel 4.4 menunjukkan bahwa total nilai sekarang arus kas bersih (PV NCF) yang merupakan hasil perkalian antara arus kas bersih (NCF) dengan faktor diskonto (DF) adalah sebesar $\left(\sum_{t=1}^{n} \frac{N C F t}{(1+i)^{t}}\right) \quad$ adalah sebesar Rp.1.323.249.742. Sehingga dengan biaya investasi awal (IA) sebesar Rp.1.278.710.000 maka besar nilai NPV adalah:

$N P V=1.323 .249 .742$

$$
\begin{aligned}
& -1.278 .710 .000 \\
& =44.539 .742
\end{aligned}
$$

Hasil perhitungan NPV yang bernilai positif sebesar Rp. 44.539.742 (>0), menunjukkan bahwa investasi PLTS yang akan dikembangkan tersebut layak untuk dilaksanakan.

2. Profitability Index (PI)

Teknik Profitability Index dihitung dengan menggunakan persamaan sebagai berikut.

$$
P I=\frac{\sum_{t=1}^{n} N C F t(1+i)^{-t}}{I A}
$$

Dengan total nilai sekarang arus kas bersih sebesar Rp. 2.761.017.340 dan biaya investasi awal (IA) sebesar Rp. 2.747.800.000 maka besar nilai PI adalah :

$$
\begin{aligned}
P I= & \frac{1.323 \cdot 249.742}{1.278 .710 .000} \\
& =1,034
\end{aligned}
$$

Hasil perhitungan $\mathrm{PI}$ yang bernilai 1,034 (>1), menunjukkan bahwa investasi PLTS yang akan dikembangkan layak untuk dilaksanakan.
3. Discounted Payback Period (DPP)

Discounted Payback Period (DPP) diperoleh dengan menghitung berapa tahun nilai sekarang arus kas bersih kumulatif (kumulatif PV NCF) akan sama dengan nilai investasi awal.

Pada perhitungan ditunjukkan bahwa pada tahun ke-21, kumulatif PV NCF mendekati nilai investasi awal dengan kekurangan sebesar Rp. 9.143.279 yaitu dari Rp. 1.278.710.000 - Rp. 1.269.566.721. Dalam tahun ke-22, nilai sekarang arus kas bersih (PV NCF tahun ke-22) adalah sebesar Rp.15.301.933. Sehingga untuk dapat menutupi kekurangan investasi awal sebesar Rp. 9.143.279, maka lama waktu yang diperlukan adalah sekitar 8 bulan (0,6 dari 12 bulan) yang diperoleh dari:

$$
\frac{\text { Rp. } 9 \cdot 143 \cdot 279}{\text { Rp. } 15 \cdot 301 \cdot 933}=0,6
$$

Diperoleh DPP sekitar 21 tahun 8 bulan menunjukkan bahwa investasi PLTS yang akan dikembangkan di Stasiun kereta api Cirebon Prujakan pada jangka waktu 25 tahun yang akan datang layak untuk dilaksanakan. Hal ini karena DPP yang dihasilkan menunjukkan waktu yang lebih cepat dari periode umur proyek yang ditetapkan, yaitu 25 tahun.

\section{KESIMPULAN}

Dari pembahasan di atas, maka dapat diambil beberapa kesimpulan dari penelitian ini, antara lain:

1. Perencanaan PLTS di Stasiun kereta api Cirebon Prujakan bertujuan untuk menyuplai daya listrik minimum stasiun, yakni untuk berlangsungnya kegiatan utama. Besar daya listrik alat-alat yang penting pada stasiun ini adalah $7,375 \mathrm{~kW}$ sedangkan besar keseluruhan daya listrik stasiun adalah 14,99 kW.

2. Komponen sistem PLTS yang diperlukan untuk kebutuhan daya alatalat yang penting adalah 192 panel surya 200 Wp, 6 buah charge controller kapasitas $6,6 \mathrm{~kW}, 360$ buah baterai 1000 Ah dan 8 unit inverter 5 $\mathrm{kW}$. 
3. Berdasarkan aspek ekonomis, perencanaan ini membutuhkan biaya investasi sebesar Rp. 1.278.710.000 untuk sistem PLTS kebutuhan daya listrik kegiatan utama berupa alat-alat yang penting. Perencanaan ini bersifat menguntungkan jika dikembangkan dan pengembalian modal terjadi pada tahun ke-22 dari umur proyek 25 tahun. Keuntungan pertahun diperoleh dari bunga sebesar $11 \%$.

\section{REFERENSI}

1. Agustianingsih, Vera. (2016). Perencanaan Pembangkit Listrik Tenaga Surya 15 kWp dengan Sistem Off Grid di Desa Bantomanai, Kabupaten Gowa, Sulawesi Selatan (Jakarta: Teknik Elektro STT-PLN).

2. Santiari, Dewa Ayu Sri. (2011). Studi Pemanfaatan PLTS Sebagai catu Daya Tambahan pada Industri Perhotelan di Nusa Lembongan Bali. (Denpasar: Teknik Elektro Universitas Udayana).

3. Hajar, Ismu. (2015). Studi Perencanaan Penambahan Daya Pada Pembangkit Listrik Tenaga Surya, Pulau Salemo. (Jakarta: Teknik Elektro STT-PLN).
4. Rumbayan, Radiasi Matahari di Indonesia. (Jakarta :PT.Green Energi Indotama)

5. Liem Ek Bien. (2008). Perancangan Sistem Hibrid Pembangkit Listrik Tenaga SuryaDengan Jala-jala Listrik PLN Untuk Rumah Pekotaan, Fakultas Teknologi Industri.

6. (Sumber: http://www.satuenergi.com/2015/10/pe ngawasan-keteknikan-untukmewujudkan.html)

7. (Sumber: http://www.kompasiana.com/sanidewa nto/banyak-peluang-bingungmemanfaatkan_55296f1bf17e613f6f8b 45e9)

8. (Sumber: http://solarsuryaindonesia.com/) 